5-9-2003

\title{
"Quick-Takes" on a Few Recent Decisions in Evidence Law ... and Rule 5-407
}

Lynn McLain

University of Baltimore, Imclain@ubalt.edu

Follow this and additional works at: http://scholarworks.law.ubalt.edu/all_fac

Part of the Evidence Commons, and the Legal Education Commons

\section{Recommended Citation}

Lynn McLain, "Quick-Takes" on a Few Recent Decisions in Evidence Law ... and Rule 5-407, (2003).

Available at: http://scholarworks.law.ubalt.edu/all_fac/921

This Article is brought to you for free and open access by the Faculty Scholarship at ScholarWorks@University of Baltimore School of Law. It has been accepted for inclusion in All Faculty Scholarship by an authorized administrator of ScholarWorks@University of Baltimore School of Law. For more

information, please contact snolan@ubalt.edu. 


\title{
STATE AND LOCAL GOVERNMENT LAW INSTITUTE \\ "Quick-Takes" on a Few Recent Decisions in \\ Evidence Law ... and Rule 5-407
}

\author{
Lynn McLain, Professor \\ University of Baltimore School of Law \\ May 9, 2003
}

\section{Sufficiency of Evidence to Support Local Government's Zoning Decision: Attorney's Unsworn Statements Are Not Evidence}

Heard v. Foxshire, 145 Md. App. 695, 806 A.2d 348 (Sept. 3, 2002) (Sharer, J.) (county board of appeals' decision to grant special exception was not supported by sufficient evidence, as applicant's attorney's statement was unsworn and thus did not qualify as evidence).

\section{Condemnation}

Bern-Shaw Ltd. Partnership v. Mayor \& City Council of Baltimore, $148 \mathrm{Md}$. App. 313, 811 A.2d 869 (Dec. 3, 2002) (J. Eyler, J.).

- Comparable Sales ${ }^{1}$ : No error in admitting, over landowner's objection, evidence of price that landowner had paid for property 18 years before quick-take at issue; landowner could cross-examine witness so as to affect weight of that evidence; concept of who bears burden of proof is inapposite to what is "just compensation;"

- Jury View ${ }^{2}$ : Jury view is mandated, unless both parties sign a waiver; no undue prejudice from post-taking view of then rat-infested property, because landowner free to point out changes that occurred after taking; court affirmed jury verdict for less than experts for either side had testified to.

\section{Attorney-Client Privilege ${ }^{3}$}

\section{A. Waiver by Inadvertent Disclosure of Privileged Matter}

Elkton Care Center Assocs. Ltd. Partnership v. Quality Care Management, 145 Md. App. 532, 805 A.2d 1177 (Aug. 29, 2002) (Murphy, C.J.).

' See generally Mclain, vol. 5 MARYLAND EVIDENCE: STATE AND FEDERAL $\$ 401: 2$ at 495-97 (2d ed. 2001) (Thomson/West 1-800-328-4880 ext. 4) (hereinafter, "MARYLAND EVIDENCE").

2 See generally id. $\$ 403: 8$ at 599-601.

3 See generally vol. 6 id. $\$ \$ 503: 1-21$ at $37-118$. 


\section{- "Intermediate Text" Adopted by CSA}

Under the adopted test, in determining whether inadvertent disclosure results in waiver of the privilege, the court must consider:

"(1) the reasonableness of the precautions taken to prevent inadvertent disclosure in view of the extent of the document production; (2) the number of inadvertent disclosures; (3) the extent of the disclosure; (4) any delay [in] measures taken to rectify the disclosure; and (5) whether the overriding interests of justice would or would not be served by relieving a party of its error."

$145 \mathrm{Md}$. App. at 545 (citation omitted).

\section{- Application of Test to Facts of Case}

The trial court was held to have properly found that waiver occurred when a privileged document (from prior counsel) was included in a half-full box provided by trial counsel to opposing counsel, who tabbed the document and returned it, asking that it be copied. Thus, appellant's trial counsel had two occasions during the discovery phase to assert the privilege; raising the issue near the end of the trial was too late.

\section{B. Waiver: Maryland Public Information Act ("MPIA")}

Caffrey v. Department of Liquor Control for Montgomery County, 370 Md. 272, 805 A.2d 268 (Aug. 23, 2002) (Harrell, J.).

An unsuccessful bidder (ranked 4th of 6) for the operation and management of a county-owned retail liquor store submitted requests under the MPIA to the Montgomery County Department of Liquor Control (DLC), Board of License Commissioners (BLC), Office of Procurement (OP), and Ethics Commission (EC) for various documents relating to the relevant proposal and selection process. The county agencies -- relying on counsel's advice based on both the attorney-client and the deliberative interagency/executive privilege ${ }^{4}$ exceptions to the MPIA - produced only some of the documents. The requestor sued in circuit court.

The press had reported that the contract in question had gone to a member of the BLC. He subsequently resigned and was reprimanded by the EC. After suit was filed, the County disclosed the remaining documents -- citing the increased need for public understanding about the liquor store procurement, because of press coverage.

\footnotetext{
${ }^{4}$ See generally vol. 6 MARYLAND EVIDENCE $§ \S 509: 1-2$ at I80-210.
} 
The County filed for summary judgment, asking that the court uphold the initial nondisclosure as "reasonable and justifiable at the time," under various provisions of the MPIA. The plaintiff filed a cross-motion for summary judgment, seeking actual damages, punitive damages, and attorney's fees and costs caused by the need to file suit.

\title{
- Circuit Court's Decision
}

\section{a. Immunity of DLC pursuant to Statute}

The circuit court (Rowan, J.) held that Md. Cts. \& Jud. Proc. Code §5504 , the general provision of which makes the DLC immune "from all suits for damages," made the DLC immune from suit other than for enforcement of its contracts. The court thus declined to reach the issue whether the DLC had properly withheld 19 documents that the plaintiff had requested..

\section{b. Effect of County Charter with regard to MPIA}

The circuit court then addressed the plaintiff's argument that $\S 505$ of the Montgomery County Charter constituted a waiver of any attorney-client or executive deliberative/interagency privilege that was not reserved under the Charter. Section 505 provides:

\begin{abstract}
Any person shall have the right to inspect any document, except confidential police records, personnel records, or records of a confidential private nature as defined by law. The Council may adopt reasonable regulations for such inspection. A certified copy of any such document shall be furnished upon payment of a reasonable fee established by such regulations. This section shall not apply to a document or other material obtained or prepared in anticipation of litigation or for use in legal proceedings to which the County is a party.
\end{abstract}

The circuit court rejected the waiver argument.

\section{c. Application of MPIA}

The circuit court went on to find that the BLC, OP, and EC had proper reasons for withholding 6 of the 8 documents that they had initially declined to disclose. The court also dismissed with prejudice the plaintiff's request for actual and punitive damages under the MPIA and denied the plaintiff's motion for counsel fees and costs.

\footnotetext{
s See, as to counsel fees and costs under the MPIA, Kirwan v. The Diamondback, 352 Md. 74, 72I A.2d
} $196(1998)$. 


\section{- Court of Appeals' Decision re: Attorney's Fees and Costs}

After the Court of Special Appeals affirmed the circuit court in an unreported opinion, certiorari was sought and granted with regard only to the issue of attorney's fees and costs. The Court of Appeals (Harrell, J.) reversed and remanded.

a. Statute Did Not Immunize DLC from Suits for Attorney's Fees and Costs

The Court of Appeals reviewed de novo the circuit court's conclusion that the DLC's immunity, pursuant to Cts. \& Jud. Proc. $§ 5-504$, "from all suits for damages" included attorney's fees and costs that would otherwise be available under $\S 10-623$ (f) of the MPIA "[i]f the court determines that the complainant has substantially prevailed. ..." The Court of Appeals found that, in enacting $\S 5$ 504's precursor in 1941, the General Assembly acted with knowledge that the "American Rule" distinguishes between damages and counsel fees. Therefore, $\S 5-504$ did not preclude recovery against the DLC for attorney's fees and costs.

The Court of Appeals remanded to the circuit court to consider whether the DLC had properly withheld the sought-after documents, because that decision could affect whether the plaintiff could be considered to have "substantially prevailed." If the plaintiff had "substantially prevailed," he could be entitled to attorney's fees and costs.

b. County Charter Could Not Generally Vitiate "Mandatory Denials" under MPIA, but Could and Did Waive "Permissible Denials, " as well as Privileges County Held, that Would have Otherwise Resulted in Mandatory Denials

The Court of Appeals also remanded on the counsel fees and costs issue as to the other three defendants, because the Court of Appeals found that the circuit court had erred in its reading of the combined effect of the Charter and the MPIA.

\section{i. Effect as to MPIA's "Mandatory Denials"}

The Court of Appeals pointed out that, by virtue of the preemption doctrine, a county charter cannot generally permit the release of public records that the state statute would prohibit. $370 \mathrm{Md}$. at 302-03. It thus held first that $\S 5$ 505 of the County Charter could not effect a blanket waiver of the MPIA's provisions of "mandatory denial" of inspection in $\S \S 10-615-10-617$ :

For example, as provided in MPIA $\& 10 \sim 615$, "[a] custodian shall deny inspection of a public record or any part of a public record if:

(1) by law, the public record is privileged or confidential; or 
(2) the inspection would be contrary to:

(i) a State statute;

(ii) a federal statute or a regulation that is issued under the statute and has the force of law;

(iii) the rules adopted by the Court of Appeals; or

(iv) an order of a court of record."

$370 \mathrm{Md}$. at 296, 303.

But, because the attorney-client privilege (that would otherwise be honored by virtue of $\S 10-615(1))^{6}$ can be waived by the client, $\S 505$ "effectuates a limited waiver of that privilege." $370 \mathrm{Md}$. at 304 . The footnote following this intriguing comment suggests that the privilege as to all attorney-client privileged communications is waived, except with regard to the attorney work product doctrine. The pertinent part of the footnote provides:

Obviously, if documents qualify as "a document or other material obtained or prepared in anticipation of litigation or for use in legal proceedings to which the County is a party," they would be exempted expressly from release under $\$ 505$, quite apart from any separate common law attorney-client privilege.

Id. at $304 \mathrm{n} .18$. Therefore, the Court of Appeals held that the circuit court had erred in concluding that the BLC had properly withheld documents under the attorney-client privilege, if the documents were not "obtained or prepared in anticipation of litigation or for use in legal proceedings to which the County is a party." Id. at 311.

The same footnote then drops another bombshell, but in dictum: $\S 505$ may also "be interpreted as effectuating a waiver of [the executive] privileges [implicitly] protected under MPIA, $\S 10-615(1)$." That part of the footnote reads:

In addition, MPIA $\S 10-615(1)$ also prohibits the release of public records subject to the executive privilege. See Office of the Governor, $360 \mathrm{Md}$. at 557, $759 \mathrm{~A} .2 \mathrm{~d}$ at 269 (explaining that if the records at issue in that case were "non-disclosable under the executive privilege doctrine, then such records or parts of records were exempt from disclosure under $\$ 10-615$ (1) of the Maryland Public Information Act"). Although not relevant here (because Respondents asserted executive privilege pursuant to the permissible interagency/intraagency documents denial, see MPIA $\S 10-618(b)$ ), to the extent the executive privilege may be waived (see Hamilton $v$. Verdow, $287 \mathrm{Md} .544,570$ n. 10,414 A.2d 914,928 n.10(1980) ("Although it is said that executive privilege may be waived, United States $v$. Reynolds, 345 U.S.

${ }^{5}$ See Caffrey, $370 \mathrm{Md}$. at 285 n.7 ("In Harris v. Baltimore Stm, 330 Md. 595, 604m05, 625 A.2d 941, 945 (1993), we explained that if a "requested public record is "information relating to representation of a client," which if disclosed by the attorney, would place the attomey in violation of Maryland Rule of Professional Conduct 1.6 ('Confidentiality of Information') 'the information is confidential under $\$ 10-615(1)$ and not to be produced under the Act." ). 
[1,] 7, [59 S. Ct. 528, 532, 97 L. Ed. 727 (1953)], there is very little case law in the appellate courts with respect to waiver of an executive privilege claim.")), $\$ 505$ may also be interpreted as effectuating a waiver of that privilege as protected under MPIA $\$ 10-615(1)$.

Id. at 304 n. 18.

\section{ii. Effect as to MPIA's "Permissible Denials"}

Section 505 did, however, effect a blanket waiver of the MPIA's "permissible denials," insofar as they are broader than the limited categories excepted from disclosure by $\S 505$. Section 505 exempts only "confidential police records, personnel records, or records of a confidential nature as defined by law." The Court of Appeals interpreted the latter phrase to refer only to "confidential records regarding an individual's private matters, such as individual income tax returns, rather than to confidential records regarding, for instance, governmental or commercial information." $370 \mathrm{Md}$. at 302 . Section 505 thus effects a waiver to the extent that MPIA $\S 10-618(\mathrm{~b})$ would permit the withholding of other documents:

As delineated in MPIA $\S 10-618$, there are also records for which the custodian may deny inspection, "if the custodian believes that such inspection would be contrary to the public interest." Office of the Governor v. Washington Post, 360 Md. 520, 550-51, 759 A.2d 249, 266 (2000). Relevant here, MPIA $\S 10-618(\mathrm{~b})$ mandates that, "the custodian may deny inspection by the applicant of ... any part of an interagency or intra-agency letter or memorandum that would not be available by law to a private party in litigation with the unit."

$370 \mathrm{Md}$. at 277, 305-06. ${ }^{7}$ Therefore, the Court of Appeals held that the circuit court had erred in concluding that the EC properly withheld a document under the interagency/intraagency permissible denial category of $\S 10-618(\mathrm{~b})$.

\section{c. County Attorney Had Warned of Possibility of Caffrey Outcome}

Ironically, the Court of Appeals cited 1980 and 2000 memos from the Montgomery County Attorney's Office that had predicted the decision reached by

${ }^{7}$ See Caffrey, $370 \mathrm{Md}$. at $285 \mathrm{n} .8$ ("The 'permissible denials' section of the MPIA states, in part, that '[u]nless otherwise provided by law, if a custodian believes that inspection of a part of a public record by the applicant would be contrary to the public interest,' MPIA $\$ 10-618$, the 'custodian may deny inspection of any part of an interagency or intra-agency letter or memorandum that would not be available by law to a private party in litigation with the unit.' MPIA $\S 10-618$ (b). We explained in Office of the Governor, $360 \mathrm{Md}$. at 551,759 A.2d at 266 , that

[the] permissible exemption for interagency and intra-agency letters or memoranda to some extent reflects that part of the executive privilege doctrine encompassing letters, memoranda or similar internal government documents containing confidential opinions, deliberations, advice or recommendations from one governmental employee or official to another official for the purpose of assisting the latter official in the decision-making function."). 
the Court of Appeals. The County Attorney had proposed the following amendment to $\S 505$ of the Charter:

\begin{abstract}
Any person shall have the right to inspect any document held by County government, except confidential police records, personnel records, records of a confidential private nature as defined by law, or records that may be exempted from disclosure under the state Public Information Act or other applicable state or federal law. The Council may adopt reasonable regulations for such inspection. A certified copy of any such document shall be furnished upon payment of a reasonable fee established by such regulations. This section shall not apply to a document or other material obtained or prepared in anticipation of litigation or for use in legal proceedings to which the County is a party. (Emphasis added to indicate the added language).
\end{abstract}

$370 \mathrm{Md}$. at 308-09. But the amendment had been withdrawn before the County Council had taken final action on it. Id. at 309.

\title{
C. Federal Seventh Circuit Holds that, in Criminal Proceedings, No Attorney- Client Privilege Exists for Confidential Communications between Government Officials and Government Lawyers
}

- In Re: A Witness before the Special Grand Jury 2000-2, 288 F.3d 289 (7th Cir. 2002)

Federal prosecutors investigating a bribery scandal in the Illinois Secretary of State's Office during the previous gubernatorial administration sought to interview the attorney who had been Chief Legal Counsel to that office, during former Secretary of State Ryan's tenure. Ryan asserted his attorney-client privilege.

The federal district court granted the U.S. Attorney's motion to compel the attorney to testify about conversations he had had with Ryan in his official capacity as General Counsel. In a thoughtful opinion by Judge Diane Wood, the United States Court of Appeals for the Seventh Circuit affirmed.

[H]ere, we have a special case: the client is neither a private individual nor a private corporation. It is instead the State of Illinois itself, represented through one of its agencies. There is surprisingly little case law on whether a government agency may also be a client for purposes of this [attorney-client] privilege, but both parties here concede that, at least in the civil and regulatory context, the government is entitled to the same attorney-client privilege as any other client. ${ }^{8}$

(Emphasis added.) See supra note 6 and accompanying text. The Caffrey court assumes that the attorney-client privilege applies to communications between the Office of the County Attorney and County attornies. 
While we recognize the need for full and frank communication between government officials, we are more persuaded by the serious arguments against extending the attorney-client privilege to protect communications between government lawyers and the public officials they serve when criminal proceedings are at issue. First, government lawyers have responsibilities and obligations different from those facing members of the private bar. While the latter are appropriately concerned first and foremost with protecting their clients -- even those engaged in wrongdoing -- from criminal charges and public exposure, government lawyers have a higher, competing duty to act in the public interest.

They take an oath, separate from their bar oath, to uphold the United States Constitution and the laws of this nation (and usually the laws of the state they serve when, as was the case with Bickel [the former Chief Legal Counsel for the Office of the Secretary of State], they are state employees). Their compensation comes not from a client whose interests they are sworn to protect from the power of the state, but from the state itself and the public fisc. It would be both unseemly and a misuse of public assets to permit a public official to use a taxpayer-provided attorney to conceal from the taxpayers themselves otherwise admissible evidence of financial wrongdoing, official misconduct, or abuse of power.

Individuals and corporations are both subject to criminal liability for their transgressions. Individuals will not talk and corporations will have no incentive to conduct or cooperate in internal investigations if they know that any information disclosed may be turned over to authorities. A state agency, however, cannot be held criminally liable by either the state itself or the federal government. There is thus no need to offer the attorney-client privilege as an incentive to increase compliance with the laws.

True, individual state employees can be held liable, and many have been found guilty of crimes in this very investigation. But the privilege with which we are concerned today runs to the office, not to the employees in that office. Just as a corporate attorney has no right or obligation to keep otherwise confidential in formation from shareholders, so a government attorney should have no privilege to shield relevant information from the public citizens to whom she owes ultimate allegiance, as represented by the grand jury.

Public officials are not the same as private citizens precisely because they exercise the power of the state. With this responsibility comes also the responsibility to act in the public interest. It follows that interpersonal relationships between an attorney for the state and a government official acting in an official capacity must be subordinated to the public interest in good and open government, leaving the government lawyer duty-bound to report internal criminal violations, not to shield them from public exposure.

In the final analysis, reason and experience dictate that the lack of criminal liability for government agencies and the duty of public 
lawyers to uphold the law and foster an open and accountable government outweigh any need for a privilege in this context. An officeholder wary of becoming enmeshed in illegal acts may always consult with a private attorney, and there the privilege unquestionably would apply. While Ryan fears that our refusal to recognize a privilege will cause even the most trivial of matters to be taken to outside counsel, this strikes us as unduly alarmist.

In fact, analogous rules apply in the corporate realm, where attorneys are repeatedly admonished to advise corporate officials that they are not personal clients of the attorney and may wish to retain other counsel. These rules do not appear to have stifled corporate discussion or proved impossible to administer, and we see no reason why a similar result cannot be countenanced here.

288 F.3d at 291-94 (citations omitted).

\section{Waiver by Dissemination}

\section{Corporation Had Made Sufficient Showing that Dissemination Was Only to Those Who "Needed to Know"}

Federal Trade Comm'n v. Glaxosmithkline, 294 F.3d 141, 147-48 (D.C. Cir. 2002) (Lamberth, J.).

The United States Court of Appeals for the District of Columbia held that the district court had erred in finding that the corporate defendant had waived its attorney-client privilege. The district court had imposed a burden on the corporation to explain why each employee, or public relations or governmental affairs consultant who had received privileged information, had needed it. The Court of Appeals rejected this allocation of the burden:

The applicable standard is, as the district court recognized, whether "the documents were distributed on a 'need to know' basis or to employees that were 'authorized to speak or act' for the company." The Company's privilege log and the affidavit of Charles Kinzig establish that GSK circulated the documents in question only to specifically named employees and contractors, most of whom were attorneys or managers and all of whom "needed to provide input to the legal department and/or receive the legal advice and strategies formulated by counsel." The affidavit also states that each intended recipient was bound by corporate policy or, in the case of the contractors, by a separate understanding, to keep confidential the contents of the documents. The Company's submission thus leads ineluctably to the conclusion that no document was "disseminated beyond those persons who, because of the corporate structure, needed to know its contents."

The district court faulted GSK for not having explained "why any, let alone all, of the employees received copies of certain documents," 
and the Commission likewise claims on brief that GSK should have shown why each individual in possession of a confidential document "needed the information [therein] to carry out his/her work." These demands are overreaching. The Company's burden is to show that it limited its dissemination of the documents in keeping with their asserted confidentiality, not to justify each determination that a particular employee should have access to the information therein. Not only would that task be Herculean -- especially when the sender and the recipient are no longer with the Company -- but it is wholly unnecessary. After all, when a corporation provides a confidential document to certain specified employees or contractors with the admonition not to disseminate further its contents and the contents of the documents are related generally to the employees' corporate duties, absent evidence to the contrary we may reasonably infer that the information was deemed necessary for the employees' or contractors'

work. Compare Coastal States, 617 F.2d at 863 (confidentiality lost when organization "admitted that it does not know who has had access to the documents, and there is undisputed testimony that ... copies of the memoranda were circulated to all area offices"). We do not presume, therefore, that any business would include in a restricted circulation list a person with no reason to have access to the confidential document--that is, one who has no "need to know."

Moreover, we can imagine no useful purpose in having a court review the business judgment of each corporate official who deemed it necessary or desirable for a particular employee or contractor to have access to a corporate secret. It suffices instead that the corporation limited dissemination to specific individuals whose corporate duties relate generally to the contents of the documents. As we have seen in this case, the privilege log and the Kinzig Declaration together establish that GSK did just that, and the Company thereby demonstrated its entitlement to the attorney-client privilege. The FTC has proffered nothing to the contrary.

Our conclusion that the documents are protected by the attorney-client privilege extends also to those communications that GSK shared with its public relations and government affairs consultants. The Kinzig affidavit notes that GSK's corporate counsel "worked with these consultants in the same manner as they did with full-time employees; indeed, the consultants acted as part of a team with full-time employees regarding their particular assignments" and, as a result, the consultants "became integral members of the team assigned to deal with issues [that] ... were completely intertwined with [GSK's] litigation and legal strategies." In these circumstances, "there is no reason to distinguish between a person on the corporation's payroll and a consultant hired by the corporation if each acts for the corporation and possesses the information needed by attorneys in rendering legal advice."

294 F.3d at $147-48$ (citations omitted).

\section{2. "Joint Defense" or "Common Interest"}


Lasalle Bank Nat'l Ass'n v. Lehman Bros. Holdings, Inc, 209 F.R.D. 112 (D.Md. 2002) (Harvey, J.).

The United States District Court for the District of Maryland held that attorney work product and attorney-client privileged documents shared with two of the law firm's clients were protected under "joint defense" or "common interest doctrine.").

\section{E. Dual Purpose -- Legal and Business -- of Protected Work Product Possible}

LaSalle Bank, 209 F.R.D. 112 (D.Md. 2002).

Citing a federal Second Circuit decision, the district court held:

A document created because of anticipated litigation, which tends to reveal mental impressions, conclusions, opinions or theories concerning the litigation, does not lose work product protection merely because it is [also] intended to assist in the making of a business decision.

209 F.R.D. at 121.

\section{Evidence of Subsequent Remedial Measures ${ }^{9}$}

A. Maryland Rule 5-407, effective July 1, 1994, and derived from Fed. R. Evid. 407, effected a significant change in Maryland law. The Rule provides:

\section{Rule 5-407 SUBSEQUENT REMEDIAL MEASURES}

\section{(a) In General}

When, after an event, measures are taken which, if in effect at the time of the event, would have made the event less likely to occur, evidence of the subsequent measures is not admissible to prove negligence or culpable conduct in connection with the event.

(b) Admissibility for Other Purposes

This Rule does not require the exclusion of evidence of subsequent measures when offered for another purpose, such as proving ownership, control, or feasibility of precautionary measures, if controverted, or impeachment.

B. Rule 5-407 is based on a combination of policy considerations and an evaluation of the probative value of a party's having taken subsequent remedial measures.

1. For policy reasons, people should be encouraged to take subsequent remedial measures, even if the steps taken are more than the law

\footnotetext{
9 See generally vol. 5 MARYLAND EVIDENCE $\$ \$ 407: 1-2$
} 
requires of them. To allow evidence that they took such steps to be admissible against them may discourage their doing so.

See Polansky v. Ryobi America Corp., 760 F. Supp. 85 (D.Md.1991) (policy underlying Fed.R.Evid. 407 did not apply to protect defendant, when it continued to market the product in question after it introduced a safer model; nor did Fed.R.Evid. 403 require exclusion of evidence).

2. Rule 5-407 is also in part simply a specific application of the general principles enunciated in Rule 5-403. The probative value of evidence that a party remedied a situation, where offered to show that party's earlier negligence or culpability, is low and is substantially outweighed by the dangers of unfair prejudice, confusion of the issues, and misleading, distraction, or confusion of the trier of fact. See Columbia v. Hawthorne, 144 U.S. 202, 12 S. Ct. 591 (1892); Tuer v. McDonald, 347 Md. 507, $523 \&$ n.8, 701 A.2d 1101 (1997); Ziehm v. United Elec. L. \& P. Co., 104 Md. 48, 61, 64 A. 61 (1906).

On the other hand, when pursuant to Rule 5-407(b) the evidence is offered to prove any purpose other than fault, such as ownership or control when the defendant denies ownership or control, its probative value on that other proposition may be greatly enhanced.

\section{Applicability of Rule 5-407: What Are Subsequent Remedial Measures?}

1. They must be subsequent to the incident, e.g., accident, giving rise to liability.

2. Remedial measures include:

a. Repairs (e.g., replacing rotten boards);

b. Adding protective devices (e.g., adding a fence or a handrail);

c. Rule/procedure changes (e.g., requiring a hospital employee to wheel a patient out to the car awaiting the patient);

d. Personnel changes (e.g., firing a bad driver);

e. Product design change; directions or warning letter.

3. Remedial measures do not necessarily include investigative reports disclosing defects, and later leading to the taking of remedial measures. Prentiss \& Carlisle v. Koehring-Waterous, 972 F.2d 6 (1st Cir. 1992); Swann v. Prudential Ins. Co., 95 Md. App. 365, 375-76, 620 A.2d 
989, 994 (1993) (consultant's report on elevator safety, prepared at request of building owner nine months after accident, was not a subsequent remedial measure, because it was not a change in owner's conduct), rev'd on other grounds, 334 Md. 231, 638 A.2d 762 (1994). But see Complaint of Consolidation Coal Co., 123 F.3d 126, 136 (3d Cir. 1997).

In BGE v. Flippo, 112 Md. App. 75, 100-02, 684 A.2d 456 (1996), Judge Bloom, writing for the Court of Special Appeals, stated:

\begin{abstract}
When an objection is made that plaintiffs counsel is attempting to introduce evidence of a "remedial measure" that should be excluded under Rule $5-407$ (a), the trial judge must make a factual determination as to whether the testimony sought to be elicited would be about a subsequent remedial measure within Rule 5-407(a) and, if so, whether it would be admissible under Rule 5407 (b). Such factual findings by the trial judge are entitled to great deference and will not be disturbed unless clearly erroneous, i.e, unsupported by any substantial evidence. Heat \& Power Corp. v. Air Products \& Chemicals. Inc., 320 Md. 584, 578 A.2d 1202 (1990); Mayor of Rockville v. Walker, $100 \mathrm{Md}$. App. 240, 640 A.2d 751 (1994); Md. Rule 8-131(c).
\end{abstract}

[A BGE employee]'s testimony [on cross-examination] indicated that at the [city council] meeting (which occurred about two weeks after the accident) he spoke about past safety practices of BGE [regarding climbable trees near overhead electric wires] and post-accident internal discussions involving the potential impact of the incident on those practices. He stated that the purpose of his appearance at the Bowie town meeting was solely in response to a crisis, or "damage control." Reference was made to a manual of guidelines printed in June 1993, which contained material that reflected both pre-accident practices and post-accident change of policy. Since the meeting was shortly after the accident and the guidelines were not published until about nine months later, Judge Spellbring concluded, reasonably, that the post-accident policy changes had not been formulated as of the date of the town meeting. We hold, therefore, that the trial judge's factual finding that [the employee]'s comments at the meeting did not constitute evidence of "Subsequent Remedial Measures" within the meaning of Rule 5-407 was not clearly erroneous.

(Emphasis added.)

Suggested Coping Strategy: Implement policy that future accidents, etc. be reported to counsel and that studies, etc. taken in response to accidents are to be prepared for submission to counsel, in anticipation of litigation. Studies will be shared only on a need-to-know basis.

\title{
D. When Is Admission of Evidence of Subsequent Remedial Measures Forbidden by the Rule?
}

\section{The Evidence is Inadmissible if Offered to Show Lack of Due Care, Negligence or Culpable Conduct}

Prior to the adoption of Rule 5-407, the Maryland case law held that having taken remedial measures after an accident or injury was 
inadmissible as an admission of liability, but admissible on the issue of whether the defendant had exercised due care at the time of the accident or injury. Wilson v. Morris, 317 Md. 284, 563 A.2d 392 (1989). Because admission for that purpose would tend "to prove negligence or culpable conduct," the Rule forbids it. The Rule overrules Wilson. Tuer $v$. McDonald, $347 \mathrm{Md}$. at 522-23.

\section{Who Took the Remedial Measures?}

a. Rule 5-407 applies only to the allegedly liable party's action, not to those of, e.g., other landlords or manufacturers, or of the plaintiff. See, e.g., TLT-Babcock, Inc. v. Emerson Elec. Co., 33 F.3d 397, 400 (4th Cir. 1994); Blaw-Knox Const. Equip. Co. v. Morris, $88 \mathrm{Md}$. App. 655, 660-62, 596 A.2d 679, 681-82 (1991) (no error to admit evidence of remedial measures taken not by the defendant but by a third party).

b. Evidence of remedial measures taken by persons other than the defendant is not excluded by Rule 5-407 (though its admission is subject to other Rules, including 5-403). See Middleton v. Harris Press \& Shear, Inc., 796 F.2d 747 (5th Cir. 1986) (although remedial measure evidence was not excluded under Rule 407, because measure was taken by someone other than the defendant, exclusion was proper under Rule 403, due to tendency of evidence to divert the jury's attention from the defendant's conduct at the time of manufacture).

\section{Was the Measure Voluntary, or Compelled by Governmental Directive?}

The Rules Committee advocated following the Fourth Circuit and applying the Rule to evidence of measures taken when a governmental directive requires that they be taken. See Chase v. General Motors Corp., 856 F.2d 17, 21 (4th Cir. 1988); Werner v. Upjohn Co., 628 F.2d 848, 859-60 (4th Cir. 1980). The Committee took no position on whether the governmental directive itself would or should be excluded by Rule 5-407. The Court of Appeals left these issues to development through the case law.

\section{Does the Rule Apply to Strict Liability Cases?}

a. The Court of Special Appeals has said yes, the rule applies to strict liability cases. E.g., Blaw-Knox Construction Equipment Co. v. Morris, 88 Md. App. 655 (1991). 
b. The Court of Appeals left this question to development through the case law.

c. The Maryland Rule is written - contrary to the 1997 amended federal rule - so as potentially to accommodate the release of an unreasonably dangerous product into the stream of commerce as an "event," so that remedial measures taken before injury to the plaintiff could be protected by the Rule.

\section{E. When Does the Rule Permit Admission of Evidence of Subsequent Remedial Measures (Subject to the Court's Exclusion, In Its Discretion, Pursuant to Rule 5-403)?}

\section{General Principles}

a. Because Rule 5-407 states that it "does not require the exclusion" of evidence of subsequent remedial measures when offered for a purpose other than "to prove negligence or culpable conduct," "such as proving ownership, control, or feasibility of precautionary measures, if controverted, or impeachment," the court retains discretion to exclude the evidence under Rule 5-403. See, e.g., In re Air Crash Disaster, 86 F.3d 498, 531 (6th Cir. 1996).

b. If the evidence is admitted, its opponent should request a limiting instruction under Rule 5-105.

\section{What Is Sufficient to "Controvert" an Issue?}

The Advisory Committee's Note to Federal Rule of Evidence 407 states:

The requirement that the other purpose be controverted calls for automatic exclusion unless a genuine issue be present and allows the opposing party to lay the groundwork for exclusion by making an admission. Otherwise the factors of undue prejudice, confusion of issues, misleading the jury, and waste of time remain for consideration under rule 403.

\section{Proof of Ownership, If Controverted}

For example, if a defendant denies owning the land where the plaintiff fell from a cliff, evidence of the defendant's building a fence there will be admissible for the limited purpose of proving ownership.

\section{Proof of Control, If Controverted}


For example, if a plaintiff has sued a store-owner for injuries resulting from a fall over a broken curb in front of the store at a mall, and the defendant has in its responsive pleading denied control of the curb (e.g., argues that the mall owners instead are responsible for the curb), then evidence that the store-owner has repaired the curb will be admissible for the limited purpose of proving the store-owner's control. If the storeowner had admitted control, the evidence would have been inadmissible for the purpose.

\section{Proof of Feasibility of Precautionary Measures, If Feasibility Is Controverted}

The literal view of feasibility is whether something can be done. For example, if a plaintiff had fallen from a cliff on defendant's land, and the defendant contended, in its pleadings or evidence, that a fence could not be built, the defendant would have controverted feasibility under the narrow view. But, when a subsequent remedial measure has been taken, it is highly unlikely that a defendant will assert that it could not be done.

Another broader reading of feasibility incorporates concepts of utility and practicability. What, then, does it take to controvert feasibility?

The majority rule requires that the defendant actively contest feasibility. E.g., Guilbeau v. W.W. Henry Co., 85 F.3d 1149, 1171 (5th Cir. 1996) ("Because [defendant] never claimed that it would not be feasible to make the adhesive without the solvents and sodium pentachlorophenate, its product labels used after the date of [plaintiff]'s alleged exposure were properly excluded from evidence as subsequent remedial measures."). See Gauthier v. AMF, Inc., 788 F.2d 634, 638 (9th

Cir.) ("In this case, AMF conceded that the safety devices were technologically and economically feasible but then argued that they concluded that the safety problem was not great enough to warrant the trade-off of consumer frustration, increased complexity of the product, and risk of consumer efforts to disconnect the safety device."), opinion amended, 805 F.2d 337 (9th Cir. 1986).

But not all authorities agree. See Meiler v. Heil Co., 745 F.2d 1297 (10th Cir. 1984) (silence on the issue, or failure to stipulate sufficient to "controvert" issue); Grenada Steel Indus. v. Alabama Oxygen Co., 695 F.2d 883, 888-89 (5th Cir.) ("The administration of Rule 407 could be greatly simplified if the appellate courts were to hold that in all of these [negligence and product liability] situations, feasibility of precautionary measures will be deemed "controverted" unless the defendant is prepared to make an unequivocal admission of feasibility." ) (quoting $23 \mathrm{C}$. Wright 
\& K. Graham, Federal Practice \& Procedure § 5288, at 144 (1980)), rehearing denied, 699 F.2d 1163 (5th Cir. 1983).

The current state of affairs leads to tricky calls, as in Tuer $v$. McDonald, 347 Md. 507, 524-29, 701 A.2d 1101 (1997) (Wilner, J.), affirming 112 Md. App. 121, 129-31, 684 A.2d 478 (1996) (Fischer, J.). The Court of Appeals held that a judgment call, in light of then-existing circumstances, that a particular action would have been "unsafe" (which judgment call was modified before trial) was not an assertion that the action was not feasible: "It was feasible but, in [defendant's] view, not advisable," at the time of the plaintiff's decedent's surgery.

\section{Impeachment}

\section{a. Rule 5-407 Contemplates Impeachment by Contradiction}

Unlike Rules 5-408 and 5-411 that limit permissible impeachment to impeachment by bias or motive, Rule 5-407 refers to "impeachment" generally. Rule 5-407, therefore, contemplates impeachment by contradiction, at least in some circumstances.

\section{b. "Mere Contradiction" As to Having Followed Applicable Standard of Care Generally Held Improper}

Evidence merely tending to show that the defendant's actions at the time of the event (e.g., the plaintiff's fall) met the applicable standard of care cannot be impeached by evidence of subsequent remedial measures. To hold otherwise would be to allow the impeachment exception to swallow the rule, ${ }^{10}$ Harrison v. Sears, Roebuck \& Co., 981 F.2d 25 (1st Cir. 1992), just as Maryland's preRule (Wilson) "standard of care" exception had done.

c. Impeachment by contradiction should be permitted only when the evidence has high probative value for that purpose, for example, if a witness testifies that the change was not made, that the condition was in the post-repair condition at the time of the accident, or when a witness has spoken in the superlative. For example, if the defendant's expert has testified that a curb height of three inches is "the safest height" for a shopping mall sidewalk, the expert could be impeached by evidence that, after the plaintiff's fall, and at the expert's recommendation, the defendant raised its curbs to five inches. See, e.g., Wood v. Morbark Industries, Inc., 70 F.3d 1994).

${ }^{10}$ See Saltzburg, Martin, and Capra, Federal Rules of Evidence Manual 487 (6th ed. 
1201, 1208 (11th Cir. 1995) (designer of wood chipper "described the seventeen-inch chute as the "safest length chute you could possible put on the machine"; "Wood's counsel should have been allowed to ask why the supposedly safest design possible was modified after the accident involving Ginger Wood. But see Stecyk v. Bell Helicopter Textron, Inc., 295 F.3d 408 (3d Cir. 2002) (2 to 1 decision) (affirming disallowance of impeachment by evidence of subsequent remedial measure, even when defense had contended that that measure "was not suited for the military environment").

Probative value also seems high if a defense witness has testified that a condition (the same one as that created by the subsequent remedial measure undertaken at the witness or the witness' employer's instance) is unsafe. For example, if a defense expert witness testified that a fence would be unsafe, evidence that the defendant had built a fence could be admissible for impeachment purposes, subject to Rule 5-403. See Dollar v. Long Mfg., Inc., 561 F.2d 613, 618 (5th Cir. 1977) (in wrongful death action arising from backhoe operator's having been crushed between control panel and safety cab, evidence of letter sent by manufacturer's design engineer to backhoe dealers warning of danger should have been admitted to impeach engineer, who testified that he believed backhoe was safe), cert. denied, 435 U.S. 996 (1978).

But the plaintiff cannot back the defendant or its witnesses into a corner so as to elicit such a statement, in order to open the door to impeachment. See Tuer v. McDonald, 347 Md. at 530 n. 10. See also State v. Thurston, 1286 Md. App. 656, 668-70, 739 A.2d 940 (1999). In Tuer, the Court of Appeals held that the defendant doctor's statement, elicited by plaintiff on direct of the doctor as an adverse witness, that restarting the anti-coagulant drug Heparin could have been unsafe, "must be read in context," as referring to the "judgment call based on his knowledge and collective experience at the time." $347 \mathrm{Md}$. at 531-32. Therefore, impeachment was properly disallowed.

If the defense introduces such testimony, the question for the trial court more likely boils down to whether the defense witness's testimony would leave an unfairly misleading impression on the jury, if impeachment is not permitted.

F. Review Problem: Plaintiff v. Railroad in negligence for wrongful death of plaintiff's wife and child killed in collision with train at railroad crossing. 
1. Plaintiff offers testimony of a witness that a week after the accident, the witness saw Railroad employees replace the wigwag signal with a flashing red light and wooden barrier.

Admissible?

2. Same testimony in 1., if Railroad alleged that the state highway commission, not the Railroad, was responsible for safety of crossings.

Admissible?

3. In 2., Defense counsel objects; Plaintiff's counsel says nothing; court sustains the objection.

Error?

4. Same testimony in 1., if Railroad's expert has testified that a wigwag signal is "the safest possible" way to mark a crossing. Your response to a 5-407 objection?

5. Testimony of Railroad engineer that Railroad lowered speed limit from 90 to 70 mph 2 months after the accident.

Admissible?

6. Testimony that Railroad fired conductor, after the accident, for having been under the influence of alcohol at the time of the accident.

Admissible?

7. Photograph of crossing taken two weeks after accident, when flashing red light and wooden barrier had been added by the Railroad. In response to defense counsel's objection, plaintiff offers photograph for permissible limited purpose, to show scene (pointing out this difference).

Response by defense counsel? 


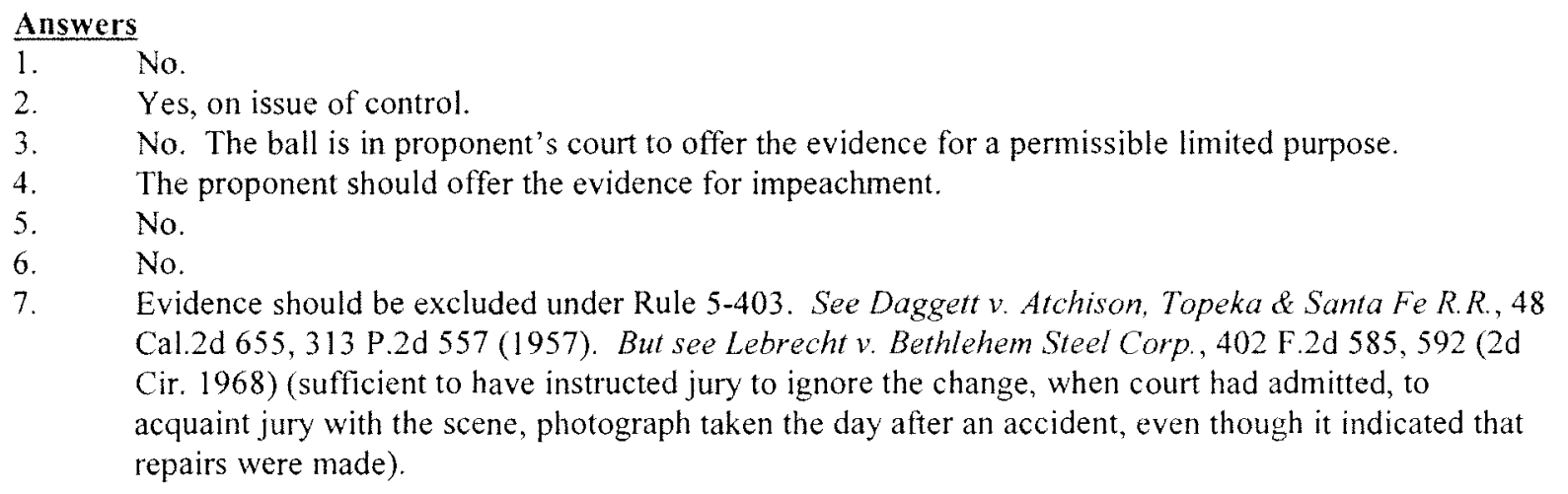

\section{Hearsay Exception for Statements Made by Person Seeking Either Medical Treatment or Diagnosis in Contemplation of Treatment}

\section{A. $\quad$ Rule 5-803(b)(4)}

Maryland Rule 5-803(b)(4) provides:

The following are not excluded by the hearsay rule, even though the declarant is available as a witness: ... [(4) Statements for Purposes of Medical Diagnosis or Treatment] Statements made for purposes of medical treatment or medical diagnosis in contemplation of treatment and describing medical history, or past or present symptoms, pain, or sensation, or the inception or general character of the cause or external sources thereof insofar as reasonably pertinent to treatment or diagnosis in contemplation of treatment.

\section{B. Hearsay Exception Does Not Apply When Possibility of Treatment is Not Contemplated by Declarant}

The circumstantial guarantee of sincerity is present only when the declarant seeks treatment, or diagnosis in order to determine whether treatment is necessary. The hearsay exception of 5-803(b)(4) is unavailable when the declarant consults a physician for other purposes, such as diagnosis (or evaluation) not intended to lead to possible treatment, which is the case when the declarant speaks with the physician solely to prepare the doctor to testify as an expert witness.

But -- perhaps because of distrusting the impartiality of the County doctors who examine children who are believed to have been possibly abused, the Court of Special Appeals, in a 2-to-1 decision in Low v. State, 119 Md. App. 413, 705 A.2d 67 (1998), misapplied the rule.

The alleged victim in Low was a twelve-year-old girl. After a social worker's referral, she was examined by a physician who worked for the Montgomery County

\footnotetext{
"See generally vol. 6A MARYLAND EVIDENCE $\$ 803(4) ; 1$ at 216-25.
} 
Department of Health and Human Services. The doctor testified to her habit of generally explaining to children that they were there due to concern about their health, because of some unhappy experience that might have happened to them. (This testimony should have been held to be sufficient, pursuant to Md. Rule 5-406 (habit or business routine), to show that the doctor had made such a statement to this child.)

The doctor performed a thorough, head-to-toe physical examination, including eyes, ears, etc., and ordered laboratory tests; she ultimately concluded that no medical treatment was needed. She testified that, if she had found that treatment was necessary, she either would have provided it herself or referred the child to her own physician, if she had one.

The trial judge credited the doctor's testimony and found the foundation laid for the 5-803(b)(4) exception as to the girl's statements to the doctor, pertinent to treatment. He thus permitted the doctor to testify not only to her physical findings that the child's "vagina and anus both showed evidence of trauma and penetration by a foreign object," but also that the child had told the doctor that "she was hurt when 'the perpetrator' put his penis in her vagina and in her 'butt' more than ten times." $119 \mathrm{Md}$. App. at 416. The doctor testified that the child had not named "the perpetrator." Other evidence at trial identified the defendant.

Judge Thieme, joined by Judge Byrnes, reversing the conviction, held that the child's statements to the doctor were not within Rule 5-803(b)(4), because the doctor saw the child "for the sole purpose of examining and detecting child abuse," as "a part of the prosecution team." Id at 415 . The majority found insufficient evidence that the child-declarant knew that the purpose of the medical examination was treatment, if treatment were necessary. The majority indicated that it was "not entirely convinced by the record" that the physician "could have" treated the child. $I d$. at 423 . On this point, it seems not to defer adequately to the trial judge's determination as to credibility.

More importantly, the majority misread Rule 5-803(b)(4), which does not require that treatment actually be provided. Judge Alpert properly dissented on this ground, because the child's statements "were, at the very least, "made for purposes of ... medical diagnosis in contemplation of treatment,' which is covered by the Rule." Id. at 429 (Alpert, J. dissenting) (emphasis omitted).

The reason that the rule so provides is that "the guarantee of diagnosis and treatment," and whether "the medical purpose of the interview or the importance of truthful answers [with regard to obtaining the proper diagnosis and, if necessary, treatment]" was explained to the declarant. State v. Hinnant, 523 S.E.2d 663, 669 (N.C. 2000). 
In light of Low, it is critical that County doctors routinely explain those matters to their patients -- especially to children -- and it would be wise for the doctors to record their having given that explanation, and the child's response, in their notes. 